\title{
Review: Are we using probiotics correctly in post-weaning piglets?
}

\author{
E. Barba-Vidal ${ }^{\dagger}$, S. M. Martín-Orúe and L. Castillejos \\ Animal Nutrition and Welfare Service, Departament de Ciència Animal i dels Aliments, Universitat Autònoma de Barcelona, 08193 Bellaterra, Spain
}

(Received 22 November 2017; Accepted 26 March 2018; First published online 3 May 2018)

Intensive farming may involve the use of diets, environments or management practices that impose physiological and psychological
stressors on the animals. In particular, early weaning is nowadays a common practice to increase the productive yield of pig farms.
Still, it is considered one of the most critical periods in swine production, where piglet performance can be seriously affected and
where they are predisposed to the overgrowth of opportunistic pathogens. Pig producers nowadays face the challenge to overcome
this situation in a context of increasing restrictions on the use of antibiotics in animal production. Great efforts are being made to
find strategies to help piglets overcome the challenges of early weaning. Among them, a nutritional strategy that has received
increasing attention in the last few years is the use of probiotics. It has been extensively documented that probiotics can reduce
digestive disorders and improve productive parameters. Still, research in probiotics so far has also been characterized as being
inconsistent and with low reproducibility from farm to farm. Scientific literature related to probiotic effects against gastrointestinal
pathogens will be critically examined in this review. Moreover, the actual practical approach when using probiotics in these
animals, and potential strategies to increase consistency in probiotic effects, will be discussed. Thus, considering the boost in
probiotic research observed in recent years, this paper aims to provide a much-needed, in-depth review of the scientific data
published to-date. Furthermore, it aims to be useful to swine nutritionists, researchers and the additive industry to critically
consider their approach when developing or using probiotic strategies in weaning piglets.

Keywords: feed additive, gut health, antibiotic alternative, nutrition, swine

\section{Implications}

This review critically examines the use of probiotics in post-weaning piglets, focusing on challenge situations, and proposes potential strategies to increase consistency in probiotic effects. Given the current lack of reproducibility commonly described with probiotic use, this approach could have significant positive effects upon the efficacy of probiotic products and economic viability of the swine industry.

\section{Introduction}

In intensive farming systems, piglets are weaned at much earlier ages (between 3 and 5 weeks) than are those that would be expected in a natural environment (around 17 weeks (Jensen and Recén, 1989)). This early weaning situation is considered one of the most critical periods in swine production, in which the animals have to face multiple stressors. Piglets undergo complex social changes, such as separation from their mothers and littermates (Pluske et al.,

\footnotetext{
${ }^{\dagger}$ Present address: Department of Animal and Poultry Science, University of Saskatchewan, Saskatchewan, Canada S7N 5A8. E-mail: emili.barba.vidal@ gmail.com
}

1997). In addition, they have to adapt to abrupt changes in the feed regime and in the environment (Weary et al., 2008), leading to a variable period of hypo- or anorexia (Bruininx, 2001). All of this happens at a time when the animals still have an immature immune system (Lallès et al., 2004), low thermoregulation (Le Dividich and Herpin, 1994) and digestive capacities (Lallès et al., 2007a), together with unstable intestinal microbiota (Wang et al., 2013). Weaning is, therefore, a time where the performance of the pigs is seriously affected (Lallès et al., 2007b), and where piglets are predisposed to the overgrowth of opportunistic pathogens like Salmonella or Escherichia coli (Pluske et al., 1997; Fouhse et al., 2016). Altogether, the process is known as a post-weaning syndrome and has been extensively studied and reviewed (Pluske et al., 1997; Lallès et al., 2007a; Heo et al., 2013).

The traditional approach to overcome this situation has been the use of in-feed antibiotics. However, in Europe, the use of antibiotics as growth promoters has been banned (Regulation (EC) No. 1831/2003), and worldwide authorities are also pressing to limit its therapeutic use (National Pork Board, 2015; European Food Safety Authority and European Medicines Agency, 2017). With this context, the pig industry and researchers are making great efforts in trying to find 
biosecurity (Madec et al., 2000), management (Weary et al., 2009; Heo et al., 2013), genetic (Lunney, 2007) and feeding (Pluske et al., 2002; Lallès et al., 2007b) strategies to help piglets overcome the challenges of weaning. Among them, a nutritional strategy that has received increasing attention in recent years is the use of probiotics. It has been extensively documented that probiotics can reduce digestive disorders and improve productive parameters (Ahasan et al., 2015; Bajagai et al., 2016). Still, research in probiotics so far has been characterized as being inconsistent and with low reproducibility from farm to farm. Consequently, although probiotics have demonstrated good potential, many farmers do not consider them to be reliable.

The objective of this review is to critically examine the use of probiotics in the post-weaning phase, focusing on challenge situations, in order to assess whether we are making good use or not of these types of products. Thus, scientific literature related to probiotic effects in experimental models of disease will be reviewed, and subsequently, a discussion about the actual practical approach when using probiotics and how it could be improved will be presented.

Considering the boost in probiotic research observed in the last few years, this paper aims to provide a much-needed, in-depth review of the scientific data published to-date. Furthermore, it aims to be useful to swine nutritionists, researchers and the additive industry to critically consider their approach when using or developing probiotic strategies in post-weaning piglets.

\section{Use of probiotics against pathogens}

A vast amount of research is published yearly in relation to probiotic capacities to improve gastrointestinal health and fight digestive pathogens. It is worth mentioning that the interest of finding probiotic strategies to fight these pathogens not only exists in animal production, but it is also present in human medicine, which, in many cases, uses pigs as a One Health approach (Mardones et al., 2017) or as a human model of disease (Meurens et al., 2012). This fact enriches the amount of information available and may be useful for the pig industry. Table 1 recalls main scientific studies published to-date, assessing the use of probiotics against pathogens in piglet experimental models of disease.

\section{Limits on therapeutic use of probiotics}

The first important factor observed is that many authors reported a positive effect by using probiotics, but there is also a considerable amount of research not supporting their use in a disease situation. In general terms, there is a higher number of articles describing beneficial effects with the use of probiotics $(>80 \%)$ rather than negative effects. However, we must consider that we may have a positive-outcome bias, as many times there may not be industrial interest to publish neutral or negative results (Fanelli, 2012). Still, in view of the current published data, it can be concluded that in the majority of cases probiotic effects against pathogens were positive, although they tended to be rather discrete.
Spectacular improvements, such as eliminating pathogen excretion or important increases in productive parameters have not been reported. Hence, with this background, a first takeaway message would be to stop looking for probiotics as direct replacements for antibiotics, as their effects are not comparable. Alternatively, as proposed by the European Food Safety Authority, probiotics should be considered as zoo-technical additives, in the category of digestibility enhancers or gut flora stabilizers (European Food Safety Authority, 2007). This change of mindset implies that, although with probiotics we may potentially target the same objectives than with antibiotics, when using probiotics our approach should be different. In other words, we should not include a probiotic and expect the same effects than with an antibiotic on its own, but we should combine them with other feed and/or management strategies with a more holistic approach.

\section{Uncertainties around probiotics effects}

Another apparent aspect of the reported results is that it is extremely difficult to discuss and extract conclusions with the data reported to-date because the conditions in which the probiotics have been tested are highly variable. There are important differences in experimental factors such as piglet days of age, treatment concentrations and dosing methods, or other aspects not reflected in Table 1, such as genetics, sanitary status, treatment days or diets. Probiotic effects are known to be treatment specific, depending on the particular strain, dose and context (Bosi and Trevisi, 2010; Li et al., 2012), and host specific, depending on host-related physiological parameters (e.g. health status and genetics) or environment (e.g. sanitary status and diet) (Collado et al., 2007; Mulder et al., 2009; Dinan and Cryan, 2016). Thus, it would be possible that probiotic strains that were not used in a certain trial turned out to be useful in another one, or vice versa. Undoubtedly, this background of uncertainty has made probiotics to be regarded as untrustworthy, being one of the main reasons preventing them from being widespread in the swine industry (Bosi and Trevisi, 2010). A first approach to reduce this variability could be to standardize conditions in which probiotics are studied to have tight control of the variables. However, although this strategy may potentially increase consistency in probiotic research, this would preclude even more the extrapolations of scientific results to the wide array of real-life situations present in pig production. Finally, another approach would be to increase basic research to investigate in-depth the physiological reasons for this variability, with the aim of developing tailored strategies to each situation.

\section{Potential risks of probiotics}

Furthermore, another important point is that results shown in Table 1 suggest that there may be potential risks when using certain probiotics in animals with damaged gut health or pathogen pressure. It has been documented in scientific literature that a baseline of bacterial translocation, possibly due to the increased para/trans-cellular permeability in the 
Table 1 Pig in vivo scientific works evaluating the use of probiotics against digestive bacterial pathogens (Escherichia coli and Salmonella sp.)

\begin{tabular}{|c|c|c|c|c|c|}
\hline \multirow[b]{2}{*}{ References } & Probiotic & Pathogen & Animals & \multirow[b]{2}{*}{ Benefits } & \multirow[b]{2}{*}{ Main results } \\
\hline & Strain, dose per pig and dosing method & Strain and dose per pig & $\begin{array}{l}\text { Days old: weaning } \\
\rightarrow \text { Inoculation }\end{array}$ & & \\
\hline De Cupere et al. (1992) & $\begin{array}{l}\text { (a) Bacillus cereus var. Toyoi }\left(1 \times 10^{9} \mathrm{cfu} / \mathrm{g}\right) \\
\text { (b) Lactobacillus spp. }\left(7.5 \times 10^{7} \mathrm{cfu} / \mathrm{g}\right) \\
\text { (c) Streptococcus faecium }\left(5.6 \times 10^{8} \mathrm{cfu} / \mathrm{g}\right) \\
\text { Included in feed }\end{array}$ & Escherichia coli $0141 \mathrm{~K} 85$ (109 cfu) & $28 \rightarrow 30$ & No & $\begin{array}{l}\text { No improvements on clinical symptoms or mortality. } \\
\text { No improvements on fecal E. coli shedding }\end{array}$ \\
\hline Shu et al. (2001) & $\begin{array}{l}\text { Bifidobacterium lactis HN019 (109 cfu/day) } \\
\text { Oral administration }\end{array}$ & E. coli sp. & $\begin{array}{c}21 \rightarrow \text { natural } \\
\text { acquisition }\end{array}$ & Yes & $\begin{array}{l}\text { Reduced diarrhea scores and fecal shedding of } E \text {. coli. } \\
\text { Improved animal performance. Increased T-cell } \\
\text { differentiation and pathogen-specific antibody titers }\end{array}$ \\
\hline Bhandari et al. (2008) & $\begin{array}{l}\text { Bacillus subtilis }\left(6 \times 10^{8} \mathrm{cfu} / \mathrm{kg}\right) \\
\text { Included in feed }\end{array}$ & E. coli $\mathrm{K} 88\left(4 \times 10^{10} \mathrm{cfu}\right)$ & $17 \rightarrow 24$ & Yes & $\begin{array}{l}\text { Reduced diarrhea scores and mortality. Modulated } \\
\text { microbial diversity. }\end{array}$ \\
\hline Lessard et al. (2009) & $\begin{array}{l}\text { (a) Pediococcus acidilactici } \\
\text { (b) Saccharomyces cerevisiae } \\
\text { (c) P. acidilactici + S. cerevisiae } \\
\text { Lactation }\left(10^{9} \mathrm{cfu}\right) . \text { Oral administration } \\
\text { Weaning }\left(10^{9} \mathrm{cfu} / \mathrm{kg}\right) \text {. Included in feed }\end{array}$ & E. coli 0149: F4 K88 (10 $\mathrm{cfu})$ & $\begin{array}{l}21 \rightarrow \\
49+50+51\end{array}$ & Yes & $\begin{array}{l}\text { Before challenge: }(a) \text { increased T-cell differentiation. } \\
\text { After challenge: }(a, b, c) \text { Reduced bacterial } \\
\text { translocation. (b) Increased ileal immunoglobulins }\end{array}$ \\
\hline Zhang et al. (2010) & $\begin{array}{l}\text { Lactobacillus rhamnosus GG (10 }{ }^{11} \text { cfu/day) } \\
\text { Oral administration }\end{array}$ & ETEC 149: K91, K88ac $\left(10^{10} \mathrm{cfu}\right)$ & $18 \rightarrow 26$ & Yes & $\begin{array}{l}\text { Reduced diarrhea scores and fecal coliform shedding. } \\
\text { Modulated microbial diversity. Increased jejunal } \\
\text { immunoglobulins. Modulated systemic inflammatory } \\
\text { cytokines }\end{array}$ \\
\hline Bhandari et al. (2010) & $\begin{array}{l}\text { E. coli }\left(4.5 \times 10^{12} \mathrm{cfu}\right) \\
\text { Included in feed (daily mix) }\end{array}$ & E. coli K88 $\left(1.2 \times 10^{11} \mathrm{cfu}\right)$ & $21 \rightarrow 27$ & Yes & Reduced ETEC in ileum. Improved animal performance \\
\hline Wang et al. (2009) & $\begin{array}{l}\text { Lactobacillus fermentum } 15007\left(2 \times 10^{9} \mathrm{cfu}\right) \\
\text { Oral administration }\end{array}$ & E. coli K88ac $\left(2 \times 10^{9} \mathrm{cfu}\right)$ & $21 \rightarrow 21$ & Yes & $\begin{array}{l}\text { Increased T-cell differentiation and ileum cytokine } \\
\text { expression }\end{array}$ \\
\hline $\begin{array}{l}\text { Konstantinov et al. } \\
\text { (2008) }\end{array}$ & $\begin{array}{l}\text { Lactobacillus sobrius DSM } 16698\left(10^{10} \mathrm{cfu}\right) \\
\text { Included in feed (daily mix })^{1}\end{array}$ & ETEC K88 0149 F4 $\left(1.5 \times 10^{10} \mathrm{cfu}\right)$ & $21 \rightarrow 28$ & Yes & $\begin{array}{l}\text { Reduced levels of ETEC in the ileum, improved } \\
\text { performance and increased diarrhea }\end{array}$ \\
\hline Krause et al. (2010) & $\begin{array}{l}\text { E. coli }\left(1.5 \times 10^{11} \mathrm{cfu}\right) \\
\text { Included in feed (daily mix) }\end{array}$ & E. coli $\mathrm{K} 88\left(1.4 \times 10^{10} \mathrm{cfu}\right)$ & $17 \rightarrow 24$ & Yes & $\begin{array}{l}\text { Increased animal performance and microbial diversity. } \\
\text { Reduced diarrhea scores (in presence of raw potato } \\
\text { starch) }\end{array}$ \\
\hline Daudelin et al. (2011) & $\begin{array}{l}\text { (a) Pediococcus acidilactici MA18/5 M } \\
\text { (b) S. cerevisiae SB-CNCM I- } 1079 \\
\text { (c) P. acidilactici + S. cerevisiae } \\
\text { Sows: gestation }\left(3 \times 10^{9} \mathrm{cfu}\right)+\text { lactation } \\
\quad\left(6 \times 10^{9} \mathrm{cfu}\right) \text {. Included in feed (daily mix) } \\
\text { Piglets: lactation }\left(1 \times 10^{9} \mathrm{cfu}\right) \text {. Oral } \\
\quad \text { administration } \\
\text { Weaning: } 2 \times 10^{9} \mathrm{cfu} / \mathrm{kg} \text {. Included in feed }\end{array}$ & ETEC 0149 F4 $\left(5 \times 10^{9} \mathrm{cfu}\right)$ & $21 \rightarrow 28$ & Yes & $\begin{array}{l}\text { (a, b) Reduced ETEC attachment to intestinal mucosa. } \\
(a, c) \text { Induced ileum cytokine expression }\end{array}$ \\
\hline Trevisi et al. (2011) & $\begin{array}{l}\text { L. rhamnosus GG }\left(6 \times 10^{9} \mathrm{cfu}\right) \\
\text { Included in feed (daily mix })^{1}\end{array}$ & ETEC F4 $\left(1.5 \times 10^{10} \mathrm{cfu}\right)$ & $21 \rightarrow 28$ & No & $\begin{array}{l}\text { Reduced animal performance. Increased diarrhea } \\
\text { scores. Reduced serum immunoglobulins. Tended to } \\
\text { a worse histomorphology }\end{array}$ \\
\hline
\end{tabular}




\begin{tabular}{|c|c|c|c|c|c|}
\hline & Probiotic & Pathogen & Animals & & \\
\hline References & Strain, dose per pig and dosing method & Strain and dose per pig & $\begin{array}{l}\text { Days old: weaning } \\
\rightarrow \text { Inoculation }\end{array}$ & Benefits & Main results \\
\hline Li et al. (2012) & $\begin{array}{l}\text { L. rhamnosus ACTT } 7469-\text { High }\left(10^{10} \mathrm{cfu}\right) \\
\text { and low dose }\left(10^{12} \mathrm{cfu}\right) \\
\text { Oral administration }\end{array}$ & ETEC F4 K88 $\left(10^{10} \mathrm{cfu}\right)$ & $21 \rightarrow 28$ & Yes & $\begin{array}{l}\text { High and low dose reduced fecal coliform shedding and } \\
\text { improved diarrhea scores (low dose was more } \\
\text { effective) }\end{array}$ \\
\hline $\begin{array}{l}\text { Guerra-Ordaz et al. } \\
\text { (2014) }\end{array}$ & $\begin{array}{l}\text { Lactobacillus plantarum JC1 B2028 } \\
\quad\left(2 \times 10^{10} \mathrm{cfu}\right) \\
\text { Included in feed (daily mix) })^{1}\end{array}$ & ETEC K88 $\left(1.2 \times 10^{10} \mathrm{cfu}\right)$ & $25 \rightarrow 33$ & Yes & $\begin{array}{l}\text { Improved ileal histomorphology. Reduced systemic } \\
\text { inflammatory cytokines. Improved fermentation } \\
\text { profile in ileum and colon }\end{array}$ \\
\hline Zhu et al. (2014) & $\begin{array}{l}\text { L. rhamnosus ACTT } 7469-\text { High }\left(10^{12} \mathrm{cfu}\right) \\
\text { and low }\left(10^{10} \mathrm{cfu}\right) \text { dose } \\
\text { Oral administration }\end{array}$ & ETEC F4 K88 $\left(10^{10} \mathrm{cfu}\right)$ & $21 \rightarrow 28$ & Yes & $\begin{array}{l}\text { Both doses improved diarrhea scores. Modulated ileal } \\
\text { T-cell differentiation. High dose increased serum } \\
\text { cytokine expression }\end{array}$ \\
\hline Zhou et al. (2015) & $\begin{array}{l}\text { Bacillus licheniformis DSM } 5749+\text { B. subtilis } \\
\text { DSM } 5750-\text { high }\left(8 \times 10^{8} \mathrm{cfu}\right) \text { and low } \\
\left(4 \times 10^{8} \mathrm{cfu}\right) \text { dose } \\
\text { Oral administration }\end{array}$ & ETEC 0149 F4 K88 (10 $10 \mathrm{cfu})$ & $21 \rightarrow 28$ & Yes & $\begin{array}{l}\text { Increased serum and ileal T-cell differentiation. Low } \\
\text { dose: increased jejunal cytokine expression }\end{array}$ \\
\hline Trevisi et al. (2015) & $\begin{array}{l}\text { S. cerevisiae CNCM I- } 4407 \\
\left(5 \times 10^{8} \mathrm{cfu} / \mathrm{kg}\right) \text { Included in feed } \\
\left(2 \times 10^{11} \mathrm{cfu} / \mathrm{kg}\right) \text { Oral administration }\end{array}$ & E. coli $0149 \mathrm{~F} 4 \mathrm{ac}\left(10^{8} \mathrm{cfu}\right)$ & $24 \rightarrow 31$ & Yes & $\begin{array}{l}\text { Reduced diarrhea scores. Reduced fecal ETEC shedding. } \\
\text { Modified blood metabolic profile }\end{array}$ \\
\hline Yang et al. (2016) & $\begin{array}{l}\text { B. licheniformis DSM } 5749+\text { B. subtilis DSM } \\
5750-\text { high }\left(8 \times 10^{8} \mathrm{cfu}\right) \text { and low } \\
\left(4 \times 10^{8} \mathrm{cfu}\right) \text { dose } \\
\text { Oral administration }\end{array}$ & ETEC/NTEC/EPEC F4+ $\left(10^{10} \mathrm{cfu}\right)$ & $21 \rightarrow 28$ & Yes & $\begin{array}{l}\text { Increased intestinal cytokines and epithelial barrier } \\
\text { integrity }\end{array}$ \\
\hline Zhang et al. (2017) & $\begin{array}{l}\text { B. licheniformis DSM } 5749+\text { B. subtilis DSM } \\
5750-\text { high }\left(4 \times 10^{9} \mathrm{cfu}\right) \text {, moderate } \\
\left(8 \times 10^{8} \mathrm{cfu}\right) \text { and low }\left(4 \times 10^{8} \mathrm{cfu}\right) \text { dose } \\
\text { Oral administration }\end{array}$ & ETEC 0149 F4 K88 (10 $10 \mathrm{cfu})$ & $21 \rightarrow 28$ & Yes & $\begin{array}{l}\text { Modulated microbiota and improved } \\
\text { histomorphological parameters }\end{array}$ \\
\hline $\begin{array}{l}\text { Barba-Vidal et al. } \\
\text { (2017a) }\end{array}$ & $\begin{array}{l}\text { B. longum subsp. Infantis CECT7210 } \\
\left(10^{9} \mathrm{cfu}\right) \\
\text { Oral administration }\end{array}$ & ETEC K88 $\left(5 \times 10^{9} \mathrm{cfu}\right.$ and $\left.5 \times 10^{10} \mathrm{cfu}\right)$ & $21 \rightarrow 26+27$ & Yes & $\begin{array}{l}\text { Reduced intestinal colonization of pathogens. Stimulated } \\
\text { local immune response. Effects on feed intake, microbial } \\
\text { fermentation and intestinal architecture showed a } \\
\text { differential pattern between challenged and non- } \\
\text { challenged animals (not favorable in challenged animals) }\end{array}$ \\
\hline Trevisi et al. (2017) & $\begin{array}{l}\text { S. cerevisiae CNCM I-4407 } \\
\left(5 \times 10^{8} \mathrm{cfu} / \mathrm{kg}\right) \\
\text { Included in feed }\end{array}$ & E. coli $0149 \mathrm{~F} 4 \mathrm{ac}\left(10^{8} \mathrm{cfu}\right)$ & $24 \rightarrow 31$ & Yes & $\begin{array}{l}\text { Improved intestinal architecture. Limited early } \\
\text { activation of gene sets related to impairment of } \\
\text { jejunal mucosa }\end{array}$ \\
\hline Casey et al. (2007) & $\begin{array}{l}\text { Lactobacillus murinus DPC6002 and DPC6003, } \\
\text { Lactobacillus pentosus DPC6004, }\end{array}$ & Salmonella typhimurium $\left(10^{8} \mathrm{cfu}\right)$ & $\begin{array}{l}\mathrm{N} / \mathrm{A} \rightarrow \mathrm{N} / \mathrm{A}+ \\
15+16+17\end{array}$ & Yes & $\begin{array}{l}\text { Reduced diarrhea scores. Increased animal } \\
\text { performance. Reduced fecal Salmonella shedding }\end{array}$ \\
\hline
\end{tabular}

Lactobacillus salivarius DPC6005, and

Probiotic mix $\left(4 \times 10^{9} \mathrm{cfu}\right)$ or fermentate

$\left(4 \times 10^{10} \mathrm{cfu}\right)$.

Oral administration 


\begin{tabular}{|c|c|c|c|c|c|}
\hline Szabó et al. (2009) & $\begin{array}{l}\text { E. faecium NCIMB10415 (Microencapsulated). } \\
\left.\text { Sows ( } 10^{9} \mathrm{cfu} / \mathrm{kg}\right) \text {, suckling piglets and } \\
\text { weaned piglets }\left(2.5 \text { to } 3 \times 10^{8} \mathrm{cfu} / \mathrm{kg}\right) \\
\text { Included in feed }\end{array}$ & S. typhimurium DT104 $\left(6 \times 10^{9} \mathrm{cfu}\right)$ & $14 \rightarrow 28$ & No & $\begin{array}{l}\text { Increased colonization and fecal shedding of } \\
\text { Salmonella. Increased serum immunoglobulins }\end{array}$ \\
\hline Walsh et al. (2012) & $\begin{array}{l}\text { E. faecium }+ \text { B. subtilis }+B \text {. licheniformis } \\
\left(10^{9} \mathrm{cfu} / \mathrm{L} \text { for each strain }\right) \\
\text { Included in drinking water }\end{array}$ & S. typhimurium $\left(10^{10} \mathrm{cfu}\right)$ & $19 \rightarrow 25$ & No & $\begin{array}{l}\text { Increased coliform shedding, no effect on Salmonella } \\
\text { scores. Prevented decrease in animal performance }\end{array}$ \\
\hline Kreuzer et al. (2012) & $\begin{array}{l}\text { E. faecium NCIMB10415 (Microencapsulated). } \\
\text { Sows, suckling piglets and weaned piglets } \\
\left(10^{9} \text { to } 5 \times 10^{9} \text { cfu). }\right. \\
\text { Included in feed }\end{array}$ & $\begin{array}{l}\text { S. typhimurium DT104 }\left(2 \times 10^{10} \mathrm{cfu}\right) \\
38 \text { days }\end{array}$ & $28 \rightarrow 38$ & No & $\begin{array}{l}\text { Reduced animal performance. No effect on fecal } \\
\text { Salmonella shedding. Increased pathogen } \\
\text { translocation }\end{array}$ \\
\hline Yin et al. (2014) & $\begin{array}{l}\text { (a) Lactobacillus zeae } \\
\text { (b) Lactobacillus casei } \\
\text { Fermented feed }\left(10^{9} \mathrm{cfu} / \mathrm{ml}\right)\end{array}$ & $\begin{array}{l}\text { S. typhimurium DT104 }\left(10^{6} \text { to } 10^{7} \mathrm{cfu}\right) \\
31 \text { days }\end{array}$ & $28 \rightarrow 31$ & Yes & $\begin{array}{l}\text { (a, b) Improved diarrhea scores. Decreased rectal } \\
\text { temperature, serum haptoglobin concentrations } \\
\text { and fecal Salmonella shedding. } \\
\text { (a) Reduced pathogen translocation }\end{array}$ \\
\hline Naqid et al. (2015) & $\begin{array}{l}\text { L. plantarum B2984 }\left(10^{10} \mathrm{cfu} / \text { day) }\right. \\
\text { Included in feed (daily mix) }\end{array}$ & S. typhimurium SL1344 (10 $\mathrm{cfu})$ & $28 \rightarrow 35$ & Yes & Increased serum immunoglobulins \\
\hline Upadhaya et al. (2017) & $\begin{array}{l}\text { a) B. subtilis RX7 }\left(1 \times 10^{9} \mathrm{cfu} / \mathrm{g}\right) \\
\text { b) Bacillus methylotrophicus } \mathrm{C} 14 \\
\left(1 \times 10^{9} \mathrm{cfu} / \mathrm{g}\right) \\
\text { Included in feed }\end{array}$ & S. typhimurium $\left(10^{11} \mathrm{cfu}\right)$ & $28 \rightarrow 39$ & Yes & $\begin{array}{l}\text { (a, b) Decreased Salmonella fecal shedding. Modulated } \\
\text { microflora, serum systemic inflammatory cytokines } \\
\text { and stress biomarkers }\end{array}$ \\
\hline $\begin{array}{l}\text { Barba-Vidal et al. } \\
\quad(2017 c)\end{array}$ & $\begin{array}{l}\text { B. licheniformis CECT } 4536\left(10^{9} \mathrm{cfu} / \mathrm{kg}\right) \\
\text { Included in feed }\end{array}$ & S. typhimurium $\left(5 \times 10^{8} \mathrm{cfu}\right)$ & $24 \rightarrow 31$ & Yes & $\begin{array}{l}\text { Reduced the colonization and fecal shedding of } \\
\text { Salmonella. Positive effect on some behavioral } \\
\text { displays }\end{array}$ \\
\hline $\begin{array}{l}\text { Barba-Vidal et al. } \\
\text { (2017a) }\end{array}$ & $\begin{array}{l}\text { B. Iongum subsp. Infantis CECT7210 (1099 cfu) } \\
\text { Oral administration }\end{array}$ & $\begin{array}{l}\text { S. typhimurium }\left(2 \times 10^{9} \mathrm{cfu} \text { and }\right. \\
\left.6 \times 10^{9} \mathrm{cfu}\right)\end{array}$ & $24 \rightarrow 32+34$ & Yes & $\begin{array}{l}\text { Reduced pathogen shedding. Stimulated local immune } \\
\text { response. Effects on feed intake, microbial } \\
\text { fermentation and intestinal architecture showed a } \\
\text { differential pattern between challenged and non- } \\
\text { challenged animals (not favorable in challenged } \\
\text { animals) }\end{array}$ \\
\hline $\begin{array}{l}\text { Barba-Vidal et al. } \\
\quad(2017 \mathrm{~b})\end{array}$ & $\begin{array}{l}\text { B. longum subsp. infantis CECT7210 and } \\
\text { Bifidobacterium animalis subsp. lactis BPL6 } \\
\quad\left(10^{9} \mathrm{cfu}\right) \\
\text { Oral administration }\end{array}$ & S. typhimurium $\left(5 \times 10^{8} \mathrm{cfu}\right)$ & $28 \rightarrow 35$ & Yes & $\begin{array}{l}\text { Reduced pathogen shedding. Decreased rectal } \\
\text { temperature. Decrease of diarrhea scores. } \\
\text { Worsened voluntary feed intake, villous:crypt ratio } \\
\text { and fermentation profiles. Stimulation of the } \\
\text { intestinal immune system }\end{array}$ \\
\hline Ahmed et al. (2014) & $\begin{array}{l}\text { (a) Lactobacillus reuteri avibro }\left(10^{10} \mathrm{cfu} / \mathrm{kg}\right) \\
\text { b) B. subtilis }+ \text { B. licheniformis } \\
\left(3.2 \times 10^{9} \mathrm{cfu} / \mathrm{kg}\right) \\
\text { Included in feed }\end{array}$ & $\begin{array}{l}\text { S. typhimurium KCTC2515 } \\
\qquad\left(3 \times 10^{9} \mathrm{cfu}\right)+\text { E. coli } \mathrm{KCTC} 2571 \\
\left(1 \times 10^{9} \mathrm{cfu}\right)\end{array}$ & $28 \rightarrow 28$ & Yes & $\begin{array}{l}\text { (a, b) Increased animal performance and nutrient } \\
\text { digestibility. Reduced Salmonella and E. coli } \\
\text { shedding }\end{array}$ \\
\hline
\end{tabular}

$\mathrm{N} / \mathrm{A}=$ not available

${ }^{1}$ Daily mix: probiotic suspended on a daily basis and mixed with feed. 
enterocyte determined by inflammatory stress, is normally associated with weaning (Lallès et al., 2004). This permeability has been reported to be affected by probiotic treatments such as in Trevisi et al. (2008), who reported an increase in translocation with a Bifidobacterium animalis and fructo-oligosacccharide treatment in post-weaning piglets. Consequently, an elevated risk of sepsis could be forecast in post-weaning animals when using probiotics (Verna and Lucak, 2010). Moreover, it has also been reported that some probiotics may have immune-suppressive effects in the host (Siepert et al., 2014). This effect has no disadvantageous consequence in a healthy context. Nevertheless, in the need of a rapid humoral response, the immune activation is less efficient (Bosi and Trevisi, 2010) and therefore would also be deleterious in a disease situation. Thus, in a context of increased permeability, it can been hypothesized that some probiotics could impair the immune response and increase risk of sepsis in some animals, despite the observed reductions in pathogen loads.

As stated before, the increase of basic research on probiotics is fundamental to improve the use-criteria of probiotics in the field and to obtain reproducible outcomes. Such a tailored use of probiotics requires a great amount of knowledge of probiotic intrinsic capacities and also of how probiotics modify ecological dynamics of the intestinal microbiota, depending on factors like sanitary status, genetics or feeding practices, among others. Fortunately, there has been great technological development during the last few decades. Nowadays, we have a sufficient amount of quality trials to begin to characterize the strains in relation to their mechanisms of action and interactions with the hosts. This is interesting because it opens a door to knowledge-based treatments, taking into account the context in which they are applied.

\section{How to improve the use of probiotics in early life stages}

In view of the present situation, it goes without saying that improving the use of probiotics in the swine industry relies on a drift from an empirical use to a more knowledge-based strategy. This section provides a few suggestions to be considered in the use of probiotics in early life stages, and in particular in post-weaning disorders. However, its aim is solely to provide a starting point for the reader to critically evaluate the use of probiotics, rather than a dissertation on their use.

To start with, assessment of the probiotic strains should be done in a wide range of health conditions. As commented by Bosi and Trevisi (2010), the identification of strains with positive effects in a broad range of gut health situations, and even capable of working in different species is economically interesting for the additive industry. However, in some cases, although specific strains had demonstrated positive effects in a normal physiological situation, they were reported to be detrimental in challenge situations in piglets (see Table 1). Hence, in our opinion, it would be highly recommended to characterize the possible risks of using a probiotic in a disease context, building clear differences whether probiotic usage is intended as a therapy or as prophylaxis. For instance, in human studies, a clear distinction is made between research aimed at maintaining health and that which aimed to treat a disease, and this difference has important implications when designing trials and in regulatory affairs (Hill et al., 2014).

A second issue to address is the capacity of probiotics to modulate microbiota. As commented before, until today one major interest when using probiotics has been to replace antibiotics via production of in situ antimicrobial compounds or enzymes to cure infections (Patil et al., 2015). Although some particular strains may have demonstrated effects here (Bhandari et al., 2008; Cheikhyoussef et al., 2008), their usefulness in this aspect is limited and spectacular improvements such as eliminating pathogen excretion are rarely reported (see Table 1). However, probiotics become much more powerful and valuable when we use them as 'preventive' health promoters and gut microbiota stabilizers (Simmering and Blaut, 2001). There is an increasing amount of scientific publications supporting that probiotic effects in gut ecology and/or immune stimulation may provide support to keep animals healthy (Zhang et al., 2010; Klaenhammer et al., 2012; Prieto et al., 2014; Zacarías et al., 2014). In addition, new selection criteria based on the mechanisms of action of the strains can allow the apparition of other probiotics that have not been previously considered in animal production but can enhance gut health and make it more robust. Besides, to increase control on their effects, probiotic strategies should be more focused. Strains should be selected depending on the objectives being looked for, and not as if probiotics were beneficial for everything. Effects should target specifically to a site. Targeting, for example, $M$ cells if applications seek to boost intestinal immunity by enhancing development of secretory IgA (Corthésy et al., 2007), or targeting the hypothalamic-pituitary-adrenal axis if we want to improve animal well-being and reduce effects of common stressors (Hardy et al., 2013; Zhou and Foster, 2015). In addition, some specific probiotic strains adapted to the colonic environment could be good candidates to fight gut dysbiosis (Corthésy et al., 2007), but other strains could be better to enhance productive performance based on their enzymatic hydrolysis properties (Kim et al., 2007) or biosynthetic pathways for amino acids' new synthesis (Pridmore et al., 2004). Hence, further assessment and classification of commercial probiotics in relation to their mechanisms of action are desirable, to be able to implement strategies that are more precise and oriented to specific needs of these animals.

Another point to take into account is the variability in the response to a probiotic, depending on the host or the herd in which it is introduced. It has been described how a probiotic strategy may have 'responder' and 'non-responder' individuals in a homogenous group of animals, and also how different microbial environments can determine variability among herds (Klaenhammer et al., 2012; Arora et al., 2013; Starke et al., 2013). For instance, it has been described how the genetically determined different presence of sugar complexes along the host gut surface may facilitate the adhesion 
on the glycocalix of some enteropathogens, possessing specific colonization factors (such as E. coli F18 and K88) and, possibly, of commensal bacteria (Krogfelt, 1991; Lee et al., 2013). Moreover, the emerging '-omic' technologies clearly open a window to refine our approach and understand better the interactions between a probiotic strain and the ecosystem in which it is going to be introduced. It is expected that by increasing our understanding in pig microbiome knowledge, we will identify key microbial groups of the piglets gut with an important role in maintaining a productive and disease-resistant ecosystems (Kim and Isaacson, 2015). In addition, we will eventually be able to identify the most appropriate strain (or strains) to use as specific probiotic treatments for a particular situation depending on the targeted microbial ecosystem (Sanders et al., 2013). For instance, two enterotype-like clusters have recently been identified in pig microbiota significantly correlated with performance (Ramayo-Caldas et al., 2016). Likewise, to correlate probiotic effects to specific enterotypes would reasonably reduce the variability of empirical use. On the other side, our understanding in probiotic interactions with the host and in particular with the intestinal cells gene expression has greatly improved in recent years. For example, a common mechanism for the anti-inflammatory activity of several probiotics has been described to be regulated by the micro-organisms pattern recognition receptors toll-like receptor 2 (TLR-2) (Villena et al., 2012; Tomosada et al., 2013). In addition, it has been described how selective pressures among European pig populations have derived into specific $T L R$-2 gene variants (Darfour-Oduro et al., 2016). Overall, this is interesting because it provides a common mechanism for the antiinflammatory activity of several probiotics (including different strains such as Lactobacillus spp. and Bifidobacterium spp.) (Tomosada et al., 2013). Moreover, it provides a potential biomarker for the screening and selection of new immuneregulatory strains, to be used efficiently at a population level to enhance immunity.

Furthermore, another possibility to potentiate probiotic effects would be to combine probiotics with complementary actions, with many beneficial examples reported in the bibliography (Casey et al., 2007; Lessard et al., 2009; Zhou et al., 2015; Barba-Vidal et al., 2017b). Probiotic combinations can be multi-strain probiotics, containing more than one strain of the same species or closely related species (for instance, Lactobacillus acidophilus and L. casel), or multispecies probiotics, containing strains of different probiotic species that belong to one or more genera (e.g. L. acidophilus, Bifidobacterium longum and Enterococcus faecium) (Timmerman et al., 2004). It has been suggested that the greater variety of probiotic genera present within a mixture may reduce its effectiveness, through mutual inhibition by the different species, antimicrobial compounds or competition for either nutrients or binding sites (Chapman et al., 2011 and 2012). However, multispecies probiotics have also been related to a broader spectrum of activity (e.g. inhibition of a wider variety of pathogenic bacteria), and if well-designed, a greater amount of synergism and symbiosis when different probiotic effects are combined (Timmerman et al., 2004). Hence, although bacterial combinations have a high potential, beneficial properties of different strains are not always additive (Chapman et al., 2011). This is not an easy field of research and bacterial interactions inside the pig gut ecosystem should be further explored to be able to construct effective strategies. Still, unfortunately in vivo studies comparing single strains to probiotic combinations are still rare. Additional approaches to strengthen effects could be the addition of specific prebiotic substrates (symbiotic concept) to selectively improve the growth of the introduced strain (Shenderov, 2011; Arboleya et al., 2016) or to promote a microbiota more favorable for the probiotic to exert its action (Guerra-Ordaz et al., 2014). Another option to improve and to specifically select the effects of a probiotic would be the genetic manipulation of the strain (Bjerre et al., 2016; Xu et al., 2016). However, introduction of GMO in the animal feed is nowadays a very controversial issue.

The way a probiotic is administered to the piglets can also be a critical point to consider as, sometimes, reduced stability and viability of the probiotic cells can limit the use of the potentially most beneficial strains. Some bacterial genera are particularly sensitive to be introduced in the dry feed, as they cannot stand chemical-physical conditions of the feed or the manufacturing process (Angelis et al., 2006). In this sense, the development of acclimatization procedures or protective coating to enable them to stand environmental aggression (Sewell, 2016) is a promising field of development for the use or probiotics as in-feed additives. Still, dry feed is not the only way a probiotic can be administered to piglets. Daily administration of fresh probiotic as a solid or liquid suspension by mixing it with the feed (top dressing) is a common procedure in research trials (see Table 1). However, although it may be a good strategy to increase the viability of probiotics when delivered, it is a highly time-consuming routine difficult to be implemented in commercial pig farms. Alternatively, fermented milk, suspension in milk or even suspension in water can be considered. For instance, Gebert et al. (2011) supplemented a milk replacer with a Lactobacillus probiotic strain and saw positive effects on pre-weaning animals.

Besides, early dosing of probiotics in the pre-weaning period should be considered. Gut microbiota plays a critical role in the adaptation from a neonatal-immature gut to a functional adult system, resistant to adverse ecological shifts at challenges such as weaning (Lewis et al. 2012). Hence, providing probiotics at this point could potentially permit the establishment of early and life-long health benefits (Kenny et al., 2011). Sows should be given more importance here, as many studies have shown how introducing probiotics in the sow diet is an effective way to modify the gut ecosystem and the health of piglets (Alexopoulos et al., 2004; Bohmer et al., 2006; Apic et al., 2014; Siepert et al., 2014; Kritas et al., 2015; Scharek-Tedin et al., 2015). Alternatively, the introduction of probiotic strategies via 'creep feed' is increasingly being studied (Alexopoulos et al., 2004; Shim et al., 2005; Giang et al., 2010). 
Nevertheless, results of these experiments are largely variable, probably due to the fact that piglets usually ingest small or null quantities of them (Pajor et al., 1991).

\section{Conclusions}

A systematic approach should be undertaken when designing a probiotic intervention to identify potential risk factors of the target animals, the suitability of a specific probiotic strain and the appropriateness of the dosing method. This process is difficult in pig production where a collectivity is being treated. More research is needed to further characterize the mechanisms of action of probiotics and their interaction in different gut health situations. We are, nowadays, able to make science-based prescriptions of probiotics in a limited amount of situations. However, eventually, when sufficient evidence is built up, we will be able to make reliable recommendations for every particular situation. Once at this point, probiotics will be used much more efficiently and the swine industry will be able to obtain the most by investing in these products.

\section{Acknowledgments}

The authors would like to thank Mr Chuck Simmons, native English-speaking University Instructor, for his correction of this article's language and style.

Declaration of interest

Authors declare no conflict of interest.

Ethics statement

None.

Software and data repository resources

None.

\section{References}

Ahasan A, Agazzi A, InverniKzzi G, Bontempo V and Savoini G 2015. The beneficial role of probiotics in monogastric animal nutrition and health. Journal of Dairy, Veterinary \& Animal Research 2, 1-20.

Ahmed S, Hoon J, Hong-Seok M and Chul-Ju Y 2014. Evaluation of Lactobacillus and Bacillus-based probiotics as alternatives to antibiotics in enteric microbial challenged weaned piglets. African Journal of Microbiology Research 8, 96-104.

Alexopoulos C, Georgoulakis IE, Tzivara A, Kyriakis CS, Govaris A and Kyriakis SC 2004. Field evaluation of the efficacy of a probiotic containing Bacillus licheniformis and Bacillus subtilis spores, on the health status and performance of sows and their litters. Journal of Animal Physiology and Animal Nutrition 88, 381-392.

Angelis M De, Siragusa S, Berloco M, Caputo L and Settanni L 2006. Selection of potential probiotic lactobacilli from pig feces to be used as additives in pelleted feeding. Research in Microbiology 157, 792-801.

Apic I, Savic B, Stancic I, Zivkov-Balas M, Bojkovski J, Jovanovic S, Radovic I, Zvekic D and Maksimovic Z 2014. Litters health status and growth parameters in the sows feeding diets supplemented with probiotic Actisaf Sc $47^{\circledR}$ within pregnancy or lactation. In International Symposium of Animal Science, Belgrade, Serbia.

Arboleya S, Stanton C and Ryan C 2016. Bosom buddies: the symbiotic relationship between infants and Bifidobacterium longum ssp. longum and ssp. infantis. Genetic and Probiotic Features. Annual review of 7, 1-21.
Arora T, Singh S and Sharma RK 2013. Probiotics: interaction with gut microbiome and antiobesity potential. Nutrition 29, 591-596.

Bajagai YS, Klieve AV, Dart PJ and Bryden WL 2016. Probiotics in animal nutrition - production, impact and regulation. In FAO Animal Production and Health Paper (ed. HPS Makkar), 179pp. Rome.

Barba Vidal E, Castillejos L, López Colom P, Rivero Urgell M, Muñoz JAM and Martín Orúe SM 2017a. Evaluation of the probiotic strain Bifidobacterium longum subsp. infantis CECT 7210 capacities to improve health status and fight digestive pathogens in a piglet model. Frontiers in Microbiology 8, 533 .

Barba-Vidal E, Castillejos L, Roll VFB, Cifuentes-Orjuela G, Moreno Muñoz JA and Martín-Orúe SM 2017b. The Probiotic Combination of Bifidobacterium longum subsp. infantis CECT 7210 and Bifidobacterium animalis subsp. lactis BPL6 Reduces pathogen loads and improves gut health of weaned piglets orally challenged with Salmonella typhimurium. Frontiers in Microbiology 8,1570 .

Barba-Vidal E, Roll VFB, Castillejos L, Guerra-Ordaz AA, Manteca X, Mallo JJ and Martín-Orúe SM 2017c. Response to a Salmonella typhimurium challenge in piglets supplemented with protected sodium butyrate or Bacillus licheniformis: effects on performance, intestinal health and behavior. Translational Animal Science 1, 186-200.

Bhandari SK, Opapeju FO, Krause DO and Nyachoti CM 2010. Dietary protein level and probiotic supplementation effects on piglet response to Escherichia coli K88 challenge: performance and gut microbial population. Livestock Science 133, 185-188.

Bhandari SK, Xu B, Nyachoti CM, Giesting DW and Krause DO 2008. Evaluation of alternatives to antibiotics using an Escherichia coli K88 + model of piglet diarrhea: Effects on gut microbial ecology. Journal of Animal Science 86, 836-847.

Bjerre K, Cantor MD, Nørgaard JV., Poulsen HD, Blaabjerg K, Canibe N, Jensen BB, Stuer-Lauridsen B, Nielsen B and Derkx PMF 2016. Development of Bacillus subtilis mutants to produce tryptophan in pigs. Biotechnology Letters 39, 289-295.

Bohmer BM, Kramer W and Roth-Maier DA 2006. Dietary probiotic supplementation and resulting effects on performance, health status, and microbial characteristics of primiparous sows. Journal of Animal Physiology and Animal Nutrition 90, 309-315.

Bosi P and Trevisi P 2010. New topics and limits related to the use of beneficial microbes in pig feeding. Beneficial Microbes 1, 447-454.

Bruininx E 2001. The IVOG ${ }^{\circledR}$ feeding station: a tool for monitoring the individual feed intake of group-housed weanling pigs. Journal of Animal Physiology and Animal Nutrition 85, 81-87.

Casey PG, Gardiner GE, Casey G, Bradshaw B, Lawlor PG, Lynch PB, Leonard FC, Stanton C, Ross RP, Fitzgerald GF and Hill C 2007. A Five-Strain Probiotic Combination Reduces Pathogen Shedding and Alleviates Disease Signs in Pigs Challenged with Salmonella enterica Serovar Typhimurium. Applied and Environmental Microbiology 73, 1858-1863.

Chapman CMC, Gibson GR and Rowland I 2011. Health benefits of probiotics: are mixtures more effective than single strains? European Journal of Nutrition $50,1-17$.

Chapman CMC, Gibson GR and Rowland I 2012. In vitro evaluation of singleand multi-strain probiotics: Inter-species inhibition between probiotic strains, and inhibition of pathogens. Anaerobe 18, 405-413.

Cheikhyoussef A, Pogori N, Chen W and Zhang H 2008. Antimicrobial proteinaceous compounds obtained from bifidobacteria: from production to their application. International Journal of Food Microbiology 125, 215-222.

Collado MC, Grześkowiak $Ł$ and Salminen S 2007. Probiotic strains and their combination inhibit in vitro adhesion of pathogens to pig intestinal mucosa. Current Microbiology 55, 260-265.

Corthésy B, Gaskins HR and Mercenier A 2007. Cross-talk between probiotic bacteria and the host immune system. The Journal of nutrition 137, 781S-790S.

De Cupere F, Deprez P, Demeulenaere D and Muylle E 1992. Evaluation of the effect of 3 probiotics on experimental Escherichia coli enterotoxaemia in weaned piglets. Journal of veterinary medicine. Series B 39, 277-284.

Darfour-Oduro KA, Megens H-J, Roca A, Groenen MAM and Schook LB 2016. Evidence for adaptation of porcine Toll-like receptors. Immunogenetics 68 , 179-189.

Daudelin J-F, Lessard M, Beaudoin F, Nadeau E, Bissonnette N, Boutin $Y$, Brousseau J-P, Lauzon K and Fairbrother JM 2011. Administration of probiotics 
influences F4 (K88)-positive enterotoxigenic Escherichia coli attachment and intestinal cytokine expression in weaned pigs. Veterinary research 42, 69.

Dinan TG and Cryan JF 2016. Microbes, immunity and behaviour: psychoneuroimmunology meets the microbiome. Neuropsychopharmacology 1-15.

Le Dividich J and Herpin P 1994. Effects of climatic conditions on the performance, metabolism and health status of weaned piglets: a review. Livestock Production Science 38, 79-90.

European Food Safety Authority 2007. Introduction of a Qualified Presumption of Safety (QPS) approach for assessment of selected microorganisms referred to EFSA - Opinion of the Scientific Committee. EFSA Journal 5, 587.

European Medicines Agency and European Food Safety Authority 2017. EMA and EFSA Joint Scientific Opinion on measures to reduce the need to use antimicrobial agents in animal husbandry in the European Union, and the resulting impacts on food safety (RONAFA). EFSA Journal 5, 245.

Fanelli D 2012. Negative results are disappearing from most disciplines and countries. Scientometrics 90, 891-904.

Fouhse JM, Zijlstra RT and Willing BP 2016. The role of gut microbiota in the health and disease of pigs. Animal Frontiers 6, 30.

Gebert S, Davis E, Rehberger T and Maxwell C 2011. Lactobacillus brevis strain $1 \mathrm{E} 1 \mathrm{administered}$ to piglets through milk supplementation prior to weaning maintains intestinal integrity after the weaning event. Beneficial Microbes 2, 35-45.

Giang HH, Viet TQ, Ogle B and Lindberg JE 2010. Growth performance, digestibility, gut environment and health status in weaned piglets fed a diet supplemented with potentially probiotic complexes of lactic acid bacteria. Livestock Science 129, 95-103.

Guerra-Ordaz A, Gónzalez-Ortiz G, La Regione RM, Woodward M, Collins J, Pérez JF and Martín-Orúe SM 2014. Lactulose and Lactobacillus plantarum, a potential complementary synbiotic to control postweaning colibacillosis in piglets. Applied and Environmental Microbiology 80, 4879-4886.

Hardy H, Harris J, Lyon E, Beal J and Foey AD 2013. Probiotics, prebiotics and immunomodulation of gut mucosal defences: homeostasis and immunopathology. Nutrients 5, 1869-1912.

Heo JM, Opapeju FO, Pluske JR, Kim JC, Hampson DJ and Nyachoti CM 2013. Gastrointestinal health and function in weaned pigs: a review of feeding strategies to control post-weaning diarrhoea without using in-feed antimicrobial compounds. Journal of Animal Physiology and Animal Nutrition 97, 207-237.

Hill C, Guarner F, Reid G, Gibson GR, Merenstein DJ, Pot B, Morelli L, Canani RB, Flint HJ, Salminen S, Calder PC and Sanders ME 2014. Expert consensus document: the International Scientific Association for Probiotics and Prebiotics consensus statement on the scope and appropriate use of the term probiotic. Nature Reviews. Gastroenterology \& Hepatology 11, 506-514.

Jensen P and Recén B 1989. When to wean - observations from free-ranging domestic pigs. Applied Animal Behaviour Science 23, 49-60.

Kenny M, Smidt H, Mengheri E and Miller B 2011. Probiotics - do they have a role in the pig industry ? Animal 5, 462-470.

Kim HB and Isaacson RE 2015. The pig gut microbial diversity: understanding the pig gut microbial ecology through the next generation high throughput sequencing. Veterinary Microbiology 177, 242-251.

Kim E-Y, Kim Y-H, Rhee M-H, Song J-C, Lee K-W, Kim K-S, Lee S-P, Lee I-S and Park S-C 2007. Selection of Lactobacillus sp. PSC101 that produces active dietary enzymes such as amylase, lipase, phytase and protease in pigs. The Journal of General and Applied Microbiology 53, 111-117.

Klaenhammer TR, Kleerebezem M, Kopp MV and Rescigno M 2012. The impact of probiotics and prebiotics on the immune system. Nature Reviews Immunology 12, 728-734.

Konstantinov SR, Smidt H, Akkermans ADL, Casini L, Trevisi P, De Filippi S, Bosi P and De Vos WM 2008. Feeding of Lactobacillus sobrius reduces Escherichia coli F4 levels in the gut and promotes growth of infected piglets. FEMS Microbiology Ecology 66, 599-607.

Krause DO, Bhandari SK, House JD and Nyachoti CM 2010. Response of nursery pigs to a synbiotic preparation of starch and an anti- Escherichia coli K88 probiotic. Applied and Environmental Microbiology 76, 8192-8200.

Kreuzer S, Janczyk P, Assmus J, Schmidt MFG, Brockmann GA and Nöckler K 2012. No beneficial effects evident for Enterococcus faecium NCIMB 10415 in weaned pigs infected with Salmonella enterica serovar Typhimurium DT104. Applied and Environmental Microbiology 78, 4816-4825.
Kritas SK, Marubashi T, Filioussis G, Petridou E, Christodoulopoulos G, Burriel AR, Tzivara A, Theodoridis A and Pískoriková M 2015. Reproductive performance of sows was improved by administration of a sporing bacillary probiotic (C-3102). Journal of Animal Science 93, 405.

Krogfelt KA 1991. Bacterial adhesion: genetics, biogenesis, and role in pathogenesis of fimbrial adhesins of Escherichia coli. Clinical Infectious Diseases 13, 721-735.

Lallès J-P, Bosi P, Smidt $H$ and Stokes CR 2007a. Weaning - a challenge to gut physiologists. Livestock Science 108, 82-93.

Lallès J-P, Bosi P, Smidt H and Stokes CR 2007b. Nutritional management of gut health in pigs around weaning. The Proceedings of the Nutrition Society 66, 260-268.

Lallès J-P, Boudry G, Favier C, Le Floc'h N, Luron I, Montagne L, Oswald IP, Pié S, Piel $C$ and Sève B 2004. Gut function and dysfunction in young pigs: physiology. Animal Research 53, 301-316.

Lee SM, Donaldson GP, Mikulski Z, Boyajian S, Ley K and Mazmanian SK 2013. Bacterial colonization factors control specificity and stability of the gut microbiota. Nature 501, 426-429.

Lessard M, Dupuis M, Gagnon N, Nadeau É, Matte JJ, Goulet J and Fairbrother JM 2009. Administration of Pediococcus acidilactici or Saccharomyces cerevisiae boulardii modulates development of porcine mucosal immunity and reduces intestinal bacterial translocation after Escherichia coli challenge. Journal of Animal Science 87, 922-934.

Lewis MC, Inman CF, Patel D, Schmidt B, Mulder I, Miller B, Gill BP, Pluske J, Kelly D, Stokes CR and Bailey M 2012. Direct experimental evidence that earlylife farm environment influences regulation of immune responses. Pediatric Allergy and Immunology 23, 265-269.

Li X-Q, Zhu Y-H, Zhang H-F, Yue Y, Cai Z-X, Lu Q-P, Zhang L, Weng X-G, Zhang F-J, Zhou D, Yang J-C and Wang J-F 2012. Risks associated with high-dose Lactobacillus rhamnosus in an Escherichia coli model of piglet diarrhoea: intestinal microbiota and immune imbalances. PloS one 7, e40666.

Lunney JK 2007. Advances in swine biomedical model genomics. International Journal of Biological Sciences 3, 179-184.

Madec F, Bridoux N, Cariolet R, Duval-i Y and Hampson DJ 2000. Experimental models of porcine post-weaning colibacillosis and their relationship to post-weaning diarrhoea and digestive disorders as encountered in the field. Veterinary Microbiology 15, 3-4.

Mardones FO, Hernandez-Jover M, Berezowski JA, Lindberg A, Mazet JAK and Morris RS 2017. Veterinary epidemiology: Forging a path toward one health. Preventive Veterinary Medicine 137, 147-150.

Meurens F, Summerfield A, Nauwynck H, Saif L and Gerdts V 2012. The pig: a model for human infectious diseases. Trends in Microbiology 20, 50-57.

Mulder IE, Schmidt B, Stokes CR, Lewis M, Bailey M, Aminov RI, Prosser J, Gill BP, Pluske JR, Mayer C-D, Musk CC and Kelly D 2009. Environmentally-acquired bacteria influence microbial diversity and natural innate immune responses at gut surfaces. BMC Biology 7, 79.

Naqid IA, Owen JP, Maddison BC, Gardner DS, Foster N, Tchórzewska MA, La Ragione RM and Gough KC 2015. Prebiotic and probiotic agents enhance antibody-based immune responses to Salmonella typhimurium infection in pigs. Animal Feed Science and Technology 201, 57-65.

National Pork Board (NPB) 2015. Antibiotics on the farm: what you need to know about new regulations. NPB, Des Moines, IA, USA.

Pajor E, Fraser D and Kramer D 1991. Consumption of solid food by suckling pigs: individual variation and relation to weight gain. Applied Animal Behaviour Science 32, 139-155.

Patil AK, Kumar S, Verma AK and Baghel RPS 2015. Probiotics as feed additives in weaned pigs: a review. Livestock Research International 3, 31-39.

Pluske JR, Hampson DJ and Williams IH 1997. Factors influencing the structure and function of the small intestine in the weaned pig: a review. Livestock Production Science 51, 215-236.

Pluske JR, Pethick DW, Hopwood DE and Hampson DJ 2002. Nutritional influences on some major enteric bacterial diseases of pig. Nutrition Research Reviews 15, 333-371.

Pridmore RD, Berger B, Desiere F, Vilanova D, Barretto C, Pittet A-C, Zwahlen M-C, Rouvet M, Altermann E, Barrangou R, Mollet B, Mercenier A, Klaenhammer T, Arigoni $F$ and Schell MA 2004. The genome sequence of the probiotic intestinal bacterium Lactobacillus johnsonii NCC 533. Proceedings of the National Academy of Sciences 101, 2512-2517. 
Barba-Vidal, Martín-Orúe and Castillejos

Prieto ML, O'Sullivan L, Tan SP, McLoughlin P, Hughes H, O'Donovan O, Rea MC Kent RM, Cassidy JP, Gardiner GE and Lawlor PG 2014. Evaluation of the efficacy and safety of a marine-derived Bacillus strain for use as an in-feed probiotic for newly weaned pigs. PloS one 9, e88599.

Ramayo-Caldas Y, Mach N, Lepage P, Levenez F, Denis C, Lemonnier G, Leplat J-J, Billon Y, Berri M, Doré J, Rogel-Gaillard C and Estellé J 2016. Phylogenetic network analysis applied to pig gut microbiota identifies an ecosystem structure linked with growth traits. The ISME Journal 10, 2973-2977.

Sanders ME, Guarner F, Guerrant R, Holt PR, Quigley EMM, Sartor RB, Sherman PM and Mayer EA 2013. An update on the use and investigation of probiotics in health and disease. Gut 62, 787-796.

Scharek-Tedin L, Kreuzer-Redmer S, Twardziok SO, Siepert B, Klopfleisch R, Tedin K, Zentek J and Pieper R 2015. Probiotic treatment decreases the number of CD14-expressing cells in porcine milk which correlates with several intestinal immune parameters in the piglets. Frontiers in Immunology 6, 108.

Sewell J 2016. Lactoplan. A heat-stable lactobacillus. Technical Bulletin Nutraferma No 3.

Shenderov BA 2011. Probiotic (symbiotic) bacterial languages. Anaerobe 17, 490-495.

Shim SB, Verstegen MWA, Kim IH, Kwon OS and Verdonk JMAJ 2005. Effects of feeding antibiotic-free creep feed supplemented with oligofructose, probiotics or synbiotics to suckling piglets increases the preweaning weight gain and composition of intestinal microbiota. Archives of Animal Nutrition 59, 419-427.

Shu Q, Qu F and Gill H 2001. Probiotic treatment using Bifidobacterium lactis HN019 reduces weanling diarrhea associated with rotavirus and Escherichia coli infection in a piglet model. Journal of Pediatric Gastroenterology and Nutrition 33, 171-177.

Siepert B, Reinhardt N, Kreuzer S, Bondzio A, Twardziok S, Brockmann G, Nöckler K, Szabó I, Janczyk P, Pieper R and Tedin K 2014. Enterococcus faecium NCIMB 10415 supplementation affects intestinal immune-associated gene expression in post-weaning piglets. Veterinary Immunology and Immunopathology 157, 65-77.

Simmering R and Blaut M 2001. Pro- and prebiotics - the tasty guardian angels? Applied Microbiology and Biotechnology 55, 19-28.

Starke IC, Pieper R, Neumann K, Zentek J and Vahjen W 2013. Individual responses of mother sows to a probiotic Enterococcus faecium strain lead to different microbiota composition in their offspring. Beneficial microbes 4 345-356.

Szabó I, Wieler LH, Tedin K, Scharek-Tedin L, Taras D, Hensel A, Appel B and Nöckler K 2009. Influence of a probiotic strain of Enterococcus faecium on Salmonella enterica serovar Typhimurium DT104 infection in a porcine animal infection model. Applied and Environmental Microbiology 75, 2621-2628.

Timmerman HM, Koning CJM, Mulder L, Rombouts FM and Beynen AC 2004. Monostrain, multistrain and multispecies probiotics - a comparison of functionality and efficacy. International Journal of Food Microbiology 96, 219-233.

Tomosada Y, Villena J, Murata K, Chiba E, Shimazu T, Aso H, Iwabuchi N, Xiao J, Saito $\mathrm{T}$ and Kitazawa H 2013. Immunoregulatory effect of bifidobacteria strains in porcine intestinal epithelial cells through modulation of ubiquitin-editing enzyme A20 expression. PloS one 8, e59259.

Trevisi P, Casini L, Coloretti F, Mazzoni M, Merialdi G and Bosi P 2011. Dietary addition of Lactobacillus rhamnosus GG impairs the health of Escherichia coli F4-challenged piglets. Animal 5, 1354-1360.

Trevisi P, Colombo M, Priori D, Fontanesi L, Galimberti G, Calò G, Motta V, Latorre R, Fanelli F, Mezzullo M, Pagotto U, Gherpelli Y, D'inca R and Bosi P 2015. Comparison of three patterns of feed supplementation with live Saccharomyces cerevisiae yeast on postweaning diarrhea, health status, and blood metabolic profile of susceptible weaning pigs orally challenged with Escherichia coli F4ac. Journal of Animal Science 93, 2225-2233.

Trevisi P, De Filippi S, Minieri L, Mazzoni M, Modesto M, Biavati B and Bosi P 2008. Effect of fructo-oligosaccharides and different doses of Bifidobacterium animalis in a weaning diet on bacterial translocation and Toll-like receptor gene expression in pigs. Nutrition (Burbank, Los Angeles County, Calif.) 24, 1023-1029.

Trevisi P, Latorre R, Priori D, Luise D, Archetti I, Mazzoni M, D'Inca R and Bosi P 2017. Effect of feed supplementation with live yeast on the intestinal transcriptome profile of weaning pigs orally challenged with Escherichia coli F4. Animal 11, 33-44.

Upadhaya SD, Shanmugam SK, Kang DK and Kim IH 2017. Preliminary assessment on potentials of probiotic B. subtilis RX7 and B. methylotrophicus C14 strains as an immune modulator in Salmonella-challenged weaned pigs. Tropical Animal Health and Production 49, 1065-1070.

Verna EC and Lucak S 2010. Use of probiotics in gastrointestinal disorders: what to recommend? Therapeutic Advances in Gastroenterology 3, 307-319.

Villena J, Suzuki R, Fujie H, Chiba E, Takahashi T, Tomosada Y, Shimazu T, Aso H, Ohwada S, Suda Y, Ikegami S, Itoh H, Alvarez S, Saito T and Kitazawa H 2012. Immunobiotic Lactobacillus jensenii modulates the Toll-like receptor 4-induced inflammatory response via negative regulation in porcine antigenpresenting cells. Clinical and Vaccine Immunology 19, 1038-1053.

Walsh MC, Rostagno MH, Gardiner GE, Sutton AL, Richert BT and Radcliffe JS 2012. Controlling Salmonella infection in weanling pigs through water delivery of direct-fed microbials or organic acids. Part I: effects on growth performance, microbial populations, and immune status. Journal of Animal Science 90, 261-271.

Wang M, Radlowski EC, Monaco MH, Fahey GC, Gaskins HR and Donovan SM 2013. Mode of delivery and early nutrition modulate microbial colonization and fermentation products in neonatal piglets. The Journal of Nutrition 143, 795-803.

Wang A, Yu H, Gao X, Li X and Qiao S 2009. Influence of Lactobacillus fermentum 15007 on the intestinal and systemic immune responses of healthy and $E$. coli challenged piglets. Antonie van Leeuwenhoek 96, 89-98.

Weary DM, Huzzey JM and von Keyserlingk MAG 2009. Board-invited review: using behavior to predict and identify ill health in animals. Journal of Animal Science 87, 770-777.

Weary DM, Jasper J and Hötzel MJ 2008. Understanding weaning distress. Applied Animal Behaviour Science 110, 24-41.

Xu Y-G, Yu H, Zhang L, Liu M, Qiao X-Y, Cui W, Jiang Y-P, Wang L, Li Y-J and Tang L-J 2016. Probiotic properties of genetically engineered Lactobacillus plantarum producing porcine lactoferrin used as feed additive for piglets. Process Biochemistry 51, 719-724.

Yang G-Y, Zhu Y-H, Zhang W, Zhou D, Zhai C-C and Wang J-F 2016. Influence of orally fed a select mixture of Bacillus probiotics on intestinal T-cell migration in weaned MUC4 resistant pigs following Escherichia coli challenge. Veterinary Research 47, 71.

Yin F, Farzan A, Wang Q (Chuck), Yu H, Yin Y, Hou Y, Friendship R and Gong J 2014. Reduction of Salmonella enterica Serovar Typhimurium DT104 infection in experimentally challenged weaned pigs fed a Lactobacillus -fermented feed. Foodborne Pathogens and Disease 11, 628-634.

Zacarías MF, Reinheimer J, Forzani L, Grangette C and Vinderola G 2014. Mortality and translocation assay to study the protective capacity of Bifidobacterium lactis INL1 against Salmonella typhimurium infection in mice. Beneficial Microbes 5, 427-436.

Zhang L, Xu Y, Liu H, Lai T, Ma J, Wang J and Zhu Y 2010. Evaluation of Lactobacillus rhamnosus GG using an Escherichia coli K88 model of piglet diarrhoea: effects on diarrhoea incidence, faecal microflora and immune responses. Veterinary Microbiology 141, 142-148.

Zhang W, Zhu Y-H, Zhou D, Wu Q, Song D, Dicksved J and Wang J-F 2017. Oral administration of a select mixture of Bacillus probiotics affects the gut microbiota and goblet cell function in newly weaned MUC4 resistant pigs following Escherichia coli challenge. Applied and Environmental Microbiology 83, e02747-16.

Zhou $L$ and Foster JA 2015. Neuropsychiatric disease and treatment dovepress psychobiotics and the gut-brain axis: in the pursuit of happiness. Neuropsychiatric Disease and Treatment 11, 715-723.

Zhou D, Zhu Y-H, Zhang W, Wang M-L, Fan W-Y, Song D, Yang G-Y, Jensen BB and Wang J-F 2015. Oral administration of a select mixture of Bacillus probiotics generates Tr1 cells in weaned F4ab/acR - pigs challenged with an F4+ ETEC/ VTEC/EPEC strain. Veterinary Research 46, 95

Zhu Y-H, Li X-Q, Zhang W, Zhou D, Liu H-Y and Wang J-F 2014. Dose-dependent effects of Lactobacillus rhamnosus on serum interleukin-17 production and intestinal T-cell responses in pigs challenged with Escherichia coli. Applied and Environmental Microbiology 80, 1787-1798. 